\title{
Nutritional status and anemia in Suruí Indian children, Brazilian Amazon
}

\author{
Jesem D. Y. Orellana, ${ }^{1}$ Carlos E. A. Coimbra Jr., ${ }^{2}$ \\ Ana Eliza Port Lourenço, ${ }^{3}$ Ricardo Ventura Santos $^{4}$
}

\begin{abstract}
Objective: To assess the nutritional status of Suruí Indian children aged less than 10 years by means of anthropometric measurements and determination of hemoglobin concentration levels.

Methods: The study was carried out from February to March 2005 in the Sete de Setembro Indian Reservation, located on the boundary between the states of Rondônia and Mato Grosso, Amazonia, Brazil. Height and weight were measured according to standard procedures and then compared with the National Center for Health Statistics reference values $(n=284)$. Hemoglobin concentration was determined by a portable $B$-hemoglobinometer (Hemocue) $(n=268)$.

Results: The percentages of children $\leq-2 \mathrm{z}$ scores for height for age, weight for age and weight for height were $25.4,8.1$ and $0 \%$, respectively. For children aged less than 5 years, the percentages were $31.4,12.4$ and $0 \%$. Most children had anemia (80.6\%), with a rate of up to $84.0 \%$ among those aged 6 to 59 months.

Conclusions: There is a high prevalence of protein-energy undernutrition and anemia among Suruí children. Comparison with a previous survey indicated that the prevalence of height for age deficit significantly decreased between 1987 and 2005 (from 46.3 to $26.7 \%$ in children younger than 9 years). On the other hand, $3.9 \%$ of the children were overweight in 2005, a finding that had not been reported in 1987. The prevalence of anemia did not change remarkably between these years. Despite the improvement in anthropometric parameters, the prevalence of nutritional deficit has been persistently higher than that observed in the Brazilian population at large. It is therefore necessary that systematic and regular monitoring of indigenous children's growth and development be implemented, focusing mainly on nutritional surveillance.
\end{abstract}

J Pediatr (Rio J). 2006;82(5):383-8: Malnutrition, anthropometry, hemoglobin, child health, South American Indians.

\section{Introduction}

In the last few decades, indigenous peoples in Brazil have shown accelerated demographic growth, ${ }^{1}$ which is partly due to high fertility rates. The indigenous population is predominantly young, usually with $40-50 \%$ of individuals

1. Mestre, pesquisador assistente, Centro de Pesquisa Leônidas e Maria Deane, Fundação Oswaldo Cruz, Manaus, AM, Brasil.

2. Doutor, pesquisador titular, Escola Nacional de Saúde Pública, Fundação Oswaldo Cruz (FIOCRUZ), Rio de Janeiro, RJ, Brasil.

3. Mestre e Doutoranda em Saúde Pública, Escola Nacional de Saúde Pública, FIOCRUZ, Rio de Janeiro, RJ, Brasil.

4. Doutor, pesquisador titular, Escola Nacional de Saúde Pública, FIOCRUZ, Rio de Janeiro, RJ, Brasil. Professor adjunto, Museu Nacional, Universidade Federal do Rio de Janeiro (UFRJ), Rio de Janeiro, RJ, Brasil.

Financial support: CNPq (protocol no. 470850/2004-3 and 506392/2004-0) and Ford Foundation.

Manuscript received Mar 20 2006, accepted for publication Jun 282006.

Suggested citation: Orellana JD, Coimbra Jr. CE, Lourenço AE, Santos RV. Nutritional status and anemia in Suruí Indian children, Brazilian Amazon. J Pediatr (Rio J). 2006;82:383-8. aged less than 15 years. Therefore, issues concerning the health and nutrition of this population group are of paramount importance.

Current information systems and the results of nationally representative surveys have allowed for detailed analyses of the health and nutritional conditions of Brazilian nonindigenous children. ${ }^{2,3}$ Unfortunately, the same does not apply to indigenous children, as there is no appropriate information about their health and nutrition. ${ }^{4,5}$ Recent studies have demonstrated that the health and nutrition of indigenous children are poorer than those of their nonindigenous counterparts. 4,6 The 2000 National Census data confirm high mortality rates among indigenous children in Brazil. ${ }^{7}$ The data show an infant mortality rate of 51.4/ 1,000 for self-reported indigenous people living in urban and rural areas; this rate is significantly higher than that for Brazil as a whole $(30.1 / 1,000)$. The infant mortality rate among indigenous peoples is also higher than in other underprivileged social strata in Brazil, such as Black 
children $(34.9 / 1,000)$. Surveys carried out in a number of specific indigenous groups have shown high rates of morbidity and mortality due to infectious and parasitic diseases, malnutrition and anemia, usually higher than those found among non-indigenous children. ${ }^{8-15}$

This study aimed to assess the nutritional status of Suruí indigenous children aged less than 10 years by way of anthropometric measurements and determination of hemoglobin concentration levels.

\section{Methods}

The Suruí (Pahíter) live in the Sete de Setembro Indian Reservation, in the Brazilian states of Rondônia and Mato Grosso ( $\pm 60^{\circ}-61^{\circ} \mathrm{W} ; 10^{\circ}-12^{\circ} \mathrm{S}$ ). From February to March 2005, when field work was carried out, the Suruí numbered 993 individuals, among whom 348 (35.0\%) were children aged less than 10 years. The permanent contact of the Surui with the Brazilian national society occurred in the 1960s, when their population size was substantially reduced due to epidemics. In the subsequent decades, the Suruí went through remarkable socioeconomic and environmental changes, which resulted in the breakdown of their subsistence system (based on horticulture, hunting and gathering), and in their subsequent insertion into the regional economy (coffee plantation, timber exploitation and cattle ranching). ${ }^{16,17}$

We made an attempt to include all children younger than 10 years (0-119 months) in the study. Due to logistic difficulties, we were not able to visit two of the 11 existing villages. The data were collected at the health posts of each village with the help of a Suruí health agent. Ages were obtained from vaccination certificates.

Height and weight measurements were made by a single observer following methodology recommended by the World Health Organization (WHO). ${ }^{18}$ The height of children older than 23 months was measured in the orthostatic position using a portable anthropometer (SECA), with an accuracy of $0.1 \mathrm{~cm}$. Younger children had their recumbent length measured using a pediatric anthropometer (SECA), with an accuracy of $0.1 \mathrm{~cm}$. An electronic scale (SECA, model 770), with maximum capacity for $150 \mathrm{~kg}$ and an accuracy of $0.1 \mathrm{~kg}$, was used for weight measurement. Weight of infants was obtained by weighing the mother holding the child, and then subtracting the mother's weight.

The Epi-Info software version 3.3.2 (Centers for Disease Control, Atlanta, Georgia, USA) was used to calculate $z$ score values for height for age (H/A), weight for height $(\mathrm{W} / \mathrm{H})$ and weight for age (W/A), based on the National Center for Health Statistics (NCHS) reference population. ${ }^{18,19}$ Those children with a $z$ score $\leq-2$ for height for age and weight for age were classified as presenting low height and low weight, respectively, whereas those with a $z$ score $\geq 2$ for weight for height were considered overweight. ${ }^{18}$ Data of children with $z$ score values below -4 or above +4 for any of the three indices were excluded from the analysis, given that they possibly result from misrecording.

Hemoglobin concentration was assessed in children aged 6 to 119 months with the use of a portable B-hemoglobinometer (Hemocue), following standard procedures. The cutoff points for the diagnosis of anemia were 11.0 and $11.5 \mathrm{~g} / \mathrm{dL}$ for children aged 6 to 59 months and 60 to 119 months, respectively. 20

The data were analyzed using SPSS for Windows version 9.0. Mean values were compared by Student's $t$ test, and the proportions were compared using the chisquare test.

This study is part of a broader project about the health of Suruí Indians, whose major focus is the epidemiology of tuberculosis, but which also includes the nutritional assessment of the population. The study was approved by the Research Ethics Committee of the Brazilian National School of Public Health (Escola Nacional de Saúde Pública) and by the Brazilian National Research Ethics Committee (CONEP) (protocol no. 714/2003), as well as by the National Indian Foundation (FUNAI - Fundação Nacional do Índio) (protocol no. 0361/03). A consent form was signed by the leaders of the indigenous communities surveyed.

\section{Results}

A total of 293 out of 348 children aged less than 10 years were assessed by means of anthropometry. None of the subjects refused to participate in the study. Losses occurred due to their absence when our team visited their villages ( $n=23$ ) or because the children lived in communities that were not surveyed $(n=32)$. Nine (3.1\%) children were excluded from the analysis due to incorrect data recording. Therefore, the anthropometric analyses included 284 children, corresponding to $81.6 \%$ of the total population in the age range considered.

Among children younger than 10 years, the prevalences of low $\mathrm{H} / \mathrm{A}$ and low $\mathrm{W} / \mathrm{H}$ were respectively 25.4 and $0.0 \%$ (Table 1). Statistically significant differences were not observed between males and females in relation to any of the indices $(p \geq 0.05)$. For $W / H, 3.9 \%$ of the children had a $z$ score $\geq 2$. Taking only children younger than 60 months into account (Table 2), $31.4 \%$ had low $\mathrm{H} / \mathrm{A}$ values. No cases of low $\mathrm{W} / \mathrm{H}$ were detected. A $\mathrm{z}$ score $\geq 2$ for $\mathrm{W} / \mathrm{H}$ was observed in $3.3 \%$ of the children. The frequencies of low $\mathrm{H} / \mathrm{A}$ increase remarkably after the second year of life, reaching values over $30.0 \%$. No differences between males and females were observed in this age range $(p \geq 0.05)$. 
Concerning hemoglobin concentration, two children refused to have it measured, 28 were not assessed for being outside of the visited communities and 32 were not assessed because they lived in communities that were not surveyed. Of 330 children aged between 6 and 119 months, 268 (81.2\%) were evaluated.
The prevalence of anemia reached $80.6 \%$ (Table 3 ). No differences were observed in the proportions of anemic and non-anemic children comparing males and females ( $p \geq 0.05$ ). By considering only the children aged 6 to 59 months, $84.0 \%$ were diagnosed as anemic, also without any differences between sexes ( $p \geq 0.05)$.

Table 1 - Distribution of z score values for height/age, weight/age and weight/height of Suruí children aged 0 to 119 months, state of Rondônia, Brazil, 2005

\begin{tabular}{|c|c|c|c|c|c|c|}
\hline & \multicolumn{2}{|c|}{ Male } & \multicolumn{2}{|c|}{ Female } & \multicolumn{2}{|c|}{ Combined } \\
\hline & Freq & $(\%)$ & Freq & $(\%)$ & Freq & $(\%)$ \\
\hline \multicolumn{7}{|l|}{$\mathrm{H} / \mathrm{A}$} \\
\hline$\leq-2.00$ & 38 & $24.2 \%$ & 34 & $26.8 \%$ & 72 & $25.4 \%$ \\
\hline$-1.99-1.99$ & 119 & $75.8 \%$ & 93 & $73.2 \%$ & 212 & $74.6 \%$ \\
\hline$\geq 2.00$ & - & $0.0 \%$ & - & $0.0 \%$ & - & $0.0 \%$ \\
\hline Total & 157 & $100 \%$ & 127 & $100 \%$ & 284 & $100 \%$ \\
\hline \multicolumn{7}{|l|}{ W/A } \\
\hline$\leq-2.00$ & 9 & $5.8 \%$ & 14 & $11.0 \%$ & 23 & $8.1 \%$ \\
\hline$-1.99-1.99$ & 147 & $93.6 \%$ & 110 & $86.6 \%$ & 257 & $90.5 \%$ \\
\hline$\geq 2.00$ & 1 & $0.6 \%$ & 3 & $2.4 \%$ & 4 & $1.4 \%$ \\
\hline Total & 157 & $100 \%$ & 127 & $100 \%$ & 284 & $100 \%$ \\
\hline \multicolumn{7}{|l|}{$\mathrm{W} / \mathrm{H}$} \\
\hline$\leq-2.00$ & - & $0.0 \%$ & - & $0.0 \%$ & - & $0.0 \%$ \\
\hline$-1.99-1.99$ & 152 & $96.8 \%$ & 121 & $95.3 \%$ & 273 & $96.1 \%$ \\
\hline$\geq 2.00$ & 5 & $3.2 \%$ & 6 & $4.7 \%$ & 11 & $3.9 \%$ \\
\hline Total & 157 & $100 \%$ & 127 & $100 \%$ & 284 & $100 \%$ \\
\hline
\end{tabular}

Freq = frequency $\mathrm{H} / \mathrm{A}=$ height/age; $\mathrm{W} / \mathrm{A}=$ weight/age; $\mathrm{W} / \mathrm{H}=$ weight/height.

Table 2 - Frequency distribution of Suruí children aged 0 to 59 months with z scores values $\leq-2$ for height/age and weight/age, and $z$ scores $\geq 2$ for weight/height, state of Rondônia, Brazil, 2005

\begin{tabular}{|c|c|c|c|c|c|c|c|c|c|}
\hline \multirow{2}{*}{$\begin{array}{l}\text { Age range } \\
\text { (months) }\end{array}$} & \multicolumn{3}{|c|}{ Male } & \multicolumn{3}{|c|}{ Female } & \multicolumn{3}{|c|}{ Combined } \\
\hline & $\mathbf{n}$ & z score $\leq-2$ & $\%$ & $\mathbf{n}$ & z score $\leq-2$ & $\%$ & $\mathbf{n}$ & z score $\leq-2$ & $\%$ \\
\hline \multicolumn{10}{|l|}{$\mathrm{H} / \mathrm{A}$} \\
\hline 0-11 & 13 & 2 & 15.4 & 17 & 1 & 5.9 & 30 & 3 & 10.0 \\
\hline $12-23$ & 14 & 1 & 7.1 & 16 & 8 & 50.0 & 30 & 9 & 30.0 \\
\hline $24-35$ & 18 & 8 & 44.4 & 17 & 5 & 29.4 & 35 & 13 & 37.1 \\
\hline $36-59$ & 30 & 11 & 36.7 & 28 & 12 & 42.9 & 58 & 23 & 39.7 \\
\hline Total & 75 & 22 & 29.3 & 78 & 26 & 33.3 & 153 & 48 & 31.4 \\
\hline \multicolumn{10}{|l|}{$W / A$} \\
\hline 0-11 & 13 & - & - & 17 & - & - & 30 & - & - \\
\hline $12-23$ & 14 & - & - & 16 & 2 & 12.5 & 30 & 2 & 6.7 \\
\hline $24-35$ & 18 & 4 & 22.2 & 17 & 4 & 23.5 & 35 & 8 & 22.9 \\
\hline $36-59$ & 30 & 3 & 10.0 & 28 & 6 & 21.4 & 58 & 9 & 15.5 \\
\hline Total & 75 & 7 & 9.3 & 78 & 12 & 15.4 & 153 & 19 & 12.4 \\
\hline \multicolumn{10}{|l|}{$\mathrm{W} / \mathrm{H}$} \\
\hline $0-11$ & 13 & - & - & 17 & - & - & 30 & - & - \\
\hline $12-23$ & 14 & - & - & 16 & - & - & 30 & - & - \\
\hline $24-35$ & 18 & - & - & 17 & - & - & 35 & - & - \\
\hline $36-59$ & 30 & - & - & 28 & - & - & 58 & - & - \\
\hline Total & 75 & - & - & 78 & - & - & 153 & - & - \\
\hline
\end{tabular}

$\mathrm{H} / \mathrm{A}=$ height/age; $\mathrm{W} / \mathrm{A}=$ weight/age; $\mathrm{W} / \mathrm{H}=$ weight/height. 
Table 3 - Frequency distribution of Suruí children aged 6 to 119 months, with anemia, according to age and sex, state of Rondônia, Brazil, 2005

\begin{tabular}{|c|c|c|c|c|c|c|c|c|c|}
\hline \multirow{2}{*}{$\begin{array}{l}\text { Age range } \\
\text { (months) }\end{array}$} & \multicolumn{3}{|c|}{ Male } & \multicolumn{3}{|c|}{ Female } & \multicolumn{3}{|c|}{ Combined } \\
\hline & $\mathbf{n}$ & Anemia & $\%$ & $\mathbf{n}$ & Anemia & $\%$ & $\mathbf{n}$ & Anemia & $\%$ \\
\hline $6-12$ & 10 & 10 & 100.0 & 10 & 9 & 90.0 & 20 & 19 & 95.0 \\
\hline $12-17$ & 5 & 4 & 80.0 & 6 & 5 & 83.3 & 11 & 9 & 81.8 \\
\hline $18-23$ & 10 & 9 & 90.0 & 11 & 11 & 100.0 & 21 & 20 & 95.2 \\
\hline $24-35$ & 18 & 16 & 88.9 & 17 & 14 & 82.3 & 35 & 30 & 85.7 \\
\hline $36-47$ & 17 & 11 & 64.7 & 14 & 8 & 57.1 & 31 & 19 & 61.3 \\
\hline $48-59$ & 12 & 11 & 91.7 & 14 & 13 & 92.9 & 26 & 24 & 92.3 \\
\hline $60-71$ & 13 & 11 & 84.6 & 15 & 14 & 93.3 & 28 & 25 & 89.3 \\
\hline $72-83$ & 18 & 13 & 72.2 & 8 & 7 & 87.5 & 26 & 20 & 76.9 \\
\hline $84-95$ & 12 & 8 & 66.7 & 9 & 6 & 66.7 & 21 & 14 & 66.7 \\
\hline $96-107$ & 22 & 17 & 77.3 & 5 & 5 & 100.0 & 27 & 22 & 81.5 \\
\hline 108-119 & 12 & 8 & 66.7 & 10 & 6 & 60.0 & 22 & 14 & 63.6 \\
\hline $6-119$ & 149 & 118 & 79.2 & 119 & 98 & 82.3 & 268 & 216 & 80.6 \\
\hline
\end{tabular}

No statistically significant association ( $p \geq 0.05$ ) was observed when comparing the occurrence of low $\mathrm{H} / \mathrm{A}$ and anemia in the 259 children aged less than 10 years who were simultaneously assessed by anthropometry and hemoglobin concentration.

\section{Discussion}

In Brazil, there has been a remarkable increase in the number of studies on indigenous health in the last decade. However, these studies are not enough given the wide range of social and cultural diversity observed in indigenous groups in the country. ${ }^{4} 6$ Especially in the Amazon region, indigenous peoples have been undergoing swift socioeconomic and environmental changes. Therefore, it is essential to monitor their health and nutritional conditions.

This study showed that approximately $1 / 4$ of Surui children aged less than 10 years were undernourished. A possible explanation to this lies in the predominant poor environmental conditions and in their diet as well. In Suruí communities, there is no proper system for the treatment of water and sewage. Domestic garbage is left scattered. Acute respiratory infections account for $58 \%$ of the causes of hospitalization of children younger than 10 years, followed by infectious and parasitic diseases (especially gastroenteritis), which account for $35 \%$ of hospital admissions. ${ }^{21}$ The average incidence of tuberculosis in this age group was 1,100 per 100,000 inhabitants in 2000 2004.22 Infant mortality rate was 70/1,000 in 2004, more than twice as high as the average for the general Brazilian population. ${ }^{23}$ There have been considerable dietary changes among the Suruí, and nowadays they are very dependent on industrialized products. Starch products (rice, noodles), fried food and sweets are highly predominant, with fewer meat products and fruit, contrasting to the diversified diet they used to have in the past, which was based on hunting, fishing, gathering and agriculture. 16,17

This study is unique in its contribution to the literature on the health of indigenous peoples in Brazil, since it allows for comparisons with previous nutritional surveys carried out in the same population ${ }^{13-15}$. By comparing both studies (the first one carried out in $1987^{12}$ and the present study), it is possible to observe a significant decrease in the prevalence of low H/A and low W/A in Suruí children (Figure 1). Cases of overweight, which were not detected in the 1980s, were diagnosed in the present survey. Since the 1987 survey used a different method for the determination of hemoglobin concentration (Sahli's method), 12 it is necessary to be cautious with the comparison. Notwithstanding, while in 1987 the prevalence of anemia among children aged less than 9 years was $71.2 \%$, it increased to $80.6 \%$ in 2005 .

At least two aspects should be considered when comparing the differences in anthropometric profiles of Suruí children in 1987 and 2005. The 1980s were particularly difficult for the Suruí, as they became involved in the regional economy, leading to the breakdown of their subsistence system and, consequently, to a serious food production crisis. ${ }^{16,17}$ As a consequence, there were several cases of severe malnutrition in children. ${ }^{17}$ More recently, there has been diversification of income sources in the community due to the hiring of Indians as health agents and teachers, as well as an increase in the number of individuals who are entitled to pensions and welfare benefits. Such income has played an important role in food acquisition, crucial for calorie intake, which possibly 


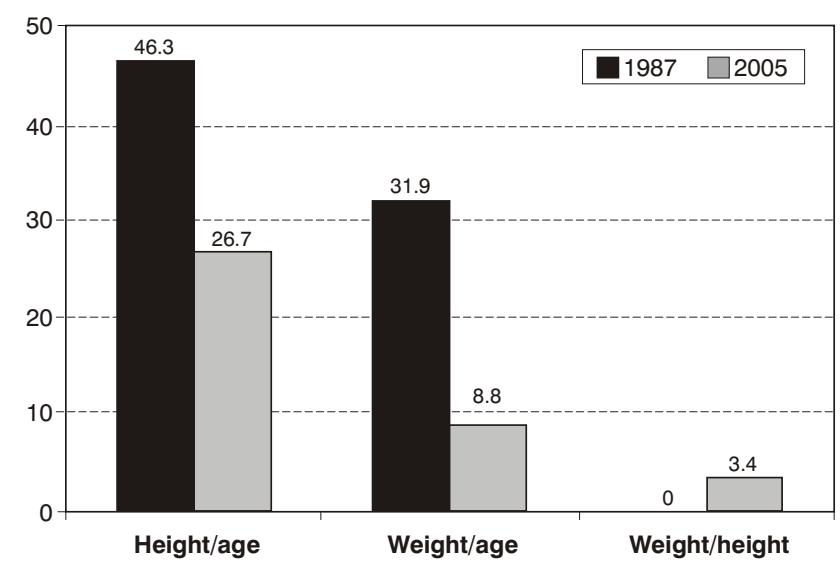

Figure 1 - Frequency distribution of Suruí children aged 0 to 107 months with $z$ scores $\leq-2$ for height/age and weight/ age, and $z$ scores $\geq 2$ for weight/height, according to sex, state of Rondônia, Brazil, 1987 and 2005

translates into a lower prevalence of nutritional deficits as well as overweight in children. In addition to an increase in calorie intake, recent changes in the healthcare system for indigenous peoples in Brazil may have also contributed to the improvement in anthropometric indicators of Suruí children. Despite its limitations, the new health system, in operation since 1999, has provided better vaccination coverage and wider access to health services. ${ }^{5}$

Even if the Suruí have overcome the nutritional crisis of the 1980s, the data of this survey showed persistently high prevalence of low height for age, affecting nearly one third of children younger than 5 years. This prevalence is considerably higher than that observed among non-indigenous children in Brazil. A national nutritional survey carried out in 1996 revealed a low prevalence of height deficits (10.5\%) among Brazilian children, ranging from $4.7 \%$ in urban areas of CentralSouthern Brazil (the most economically developed region in the country) to $25.2 \%$ in the rural Northeastern region. ${ }^{2}$ Thus the prevalence of undernutrition observed in the Suruí is significantly higher compared to national data. However, it is similar to those reported in other studies on indigenous communities in the Amazon region, which indicate values that usually surpass $30.0 \%$, and sometimes as high as 50.0\%.9-11,24,25

The high prevalence of anemia, around $80 \%$, is another aspect that confirms the poor nutritional status of Suruí children. This rate is comparable to the one observed in the 1980 s, when nearly $70 \%$ of children aged less than 9 years had anemia. ${ }^{12}$ Very possibly, anemia among the Suruí results from an iron deficient diet. It should be noted that malaria transmission in the Suruí was interrupted 2 decades ago, and that a recent parasitological survey revealed a low prevalence of hookworm infection (lower than $5.0 \%$ ), both known to be important causes of anemia in the Amazon region. 26

Based on this survey and on the observations of Suruí dietary habits, we might suggest that the decrease in the prevalences of height and weight deficits, notwithstanding the persistence of high prevalences of anemia, stem from an increase in calorie intake associated with an irondeficient diet. Other factors might have influenced the observed changes, including the impact of expanded healthcare. This hypothesis should be further investigated.

Recent studies on the nutritional status of indigenous peoples in Brazil have shown the simultaneous occurrence of undernutrition in children, and of overweight and obesity in adults. 4,10,27 This also occurs among the Suruí, with $60.5 \%$ of adults being overweight or obese. ${ }^{28}$ Although nutritional deficiencies are quite common among Suruí children, $3.9 \%$ of those younger than 10 years were overweight. The 1987 survey did not show the presence of overweight among children. ${ }^{12}$

Despite highlighting the severe situation of the Suruí, observed through the survey carried out in the late 1980s, Coimbra Jr. \& Santos ${ }^{12}$ discussed whether the observed high prevalence rates of low height for age $(48.0 \%$ in children aged less than 5 years) could not be partly due to the use of NCHS curves and supposedly inappropriate cutoff points for indigenous populations. Back then there was a paucity of studies on physical growth of indigenous children in Brazil and, at that time, prevalence rates greater than $30.0 \%$ seemed extremely high. Even though a single set of growth curves is recommended to assess nutritional status, WHO does not rule out the possibility of differences in the growth potential in children from different population groups due to genetic factors. ${ }^{18}$ Some authors suggest that the high prevalence rates of low height for age observed in Amazonian indigenous children could result from differences in growth potential, and not necessarily from undernutrition, proposing that different cutoff points from those recommended by WHO be used in nutritional surveys on indigenous communities. ${ }^{29}$

By comparing two moments and showing a remarkable decrease in the prevalence of height deficits (from 48.0 to $31.4 \%$ in children younger than 5 years) within the last 2 decades, the Suruí case study brings important theoretical and methodological implications for the nutritional assessment of indigenous populations. As highlighted previously, even if nutritional deficits have decreased, the socioeconomic and environmental conditions in which the Suruí are inserted are still poor. If living conditions remarkably improve in the short and medium run, it is expected that the prevalence of nutritional deficits might decrease even more. It should be clarified that it is not possible to build specific growth curves for indigenous populations in Brazil, since the criteria related to sample size, appropriate health status and nutrition cannot be 
met. ${ }^{18}$ Because of that, and also to allow for data comparison, it is recommended that the growth curves internationally proposed for the nutritional assessment of children continue to be used for indigenous peoples.

The results of this study have strategic implications for the health services aimed at indigenous populations in Brazil. It is necessary to implement activities that help to monitor the growth and development of indigenous children, and also anemia, placing special emphasis on nutritional surveillance.

\section{Acknowledgements}

We would like to thank the Suruí for their cooperation and interest in participating in this study. Also, our thanks to the nursing staff of Pólo Base de Cacoal, Special Indigenous Health District of Vilhena (Distrito Sanitário Especial Indígena Vilhena) for their collaboration during fieldwork. We also thank the support from researchers P.C. Basta and C.S. Palhano-Silva. Our thanks to the local representatives of the National Indian Foundation (FUNAI - Fundação Nacional do Índio) and of the National Health Foundation (FUNASA - Fundação Nacional de Saúde) in Cacoal, state of Rondônia, for their help.

\section{References}

1. Pagliaro $H$, Azevedo MM, Santos RV. Demografia dos povos indígenas no Brasil: um panorama crítico. In: Pagliaro $\mathrm{H}$, Azevedo MM, Santos RV, organizadores. Demografia dos povos indígenas no Brasil. Rio de Janeiro: Editora Fiocruz; 2005. p. 11-32.

2. Monteiro CA. Evolução da nutrição infantil nos anos 90. In: Monteiro CA, organizador. Velhos e novos males da saúde no Brasil: a evolução do país e de suas doenças. $2^{a}$ ed. São Paulo: Hucitec; 2000. p. 375-92.

3. Batista Filho M, Rissin A. A transição nutricional no Brasil: tendências regionais e temporais. Cad Saude Publica. 2003;19 Suppl 1:181-91.

4. Santos RV, Coimbra Jr. CEA. Cenários e tendências da saúde e da epidemiologia dos povos indígenas no Brasil. In: Coimbra Jr. CEA, Santos RV, Escobar AL, organizadores. Epidemiologia e saúde dos povos indígenas no Brasil. Rio de Janeiro: Editora Fiocruz; 2003. p. 13-47.

5. Garnelo L, Macedo G, Brandão LC. Os povos indígenas e a construção das políticas de saúde no Brasil. Brasília: Organização Pan-Americana da Saúde; 2003.

6. Coimbra Jr. CEA, Santos RV. Emerging health needs and epidemiological research in indigenous peoples in Brazil. In: Salzano FM, Hurtado AM, editors. Lost paradises and the ethics of research and publication. New York: Oxford University Press; 2004. p. 89-109.

7. Instituto Brasileiro de Geografia e Estatística. Tendências demográficas: uma análise dos indígenas com base nos resultados da amostra dos censos demográficos 1991 e 2000. Rio de Janeiro: Instituto Brasileiro de Geografia e Estatística; 2005.

8. Escobar AL, Rodrigues AF, Alves CLM, Orellana JDY, Santos RV, Coimbra Jr. CEA. Causas de internação hospitalar indígena em Rondônia. O distrito sanitário especial indígena de Porto Velho (1998-2001). In: Coimbra Jr. CEA, Santos RV, Escobar AL, organizadores. Epidemiologia e saúde dos povos indígenas no Brasil. Rio de Janeiro: Editora Fiocruz; 2003. p. 127-47.

9. Gugelmin SA, Santos RV, Leite MS. Crescimento físico de crianças indígenas xavantes de 5 a 10 anos de idade em Mato Grosso. J Pediatr (Rio J). 2001;77:17-22.
10. Leite MS, Santos RV, Gugelmin SA, Coimbra Jr. CEA. Crescimento físico e perfil nutricional da população indígena Xavánte de Sangradouro-Volta Grande, Mato Grosso, Brasil. Cad Saude Publica. 2006;22:265-76.

11. Escobar AL, Santos RV, Coimbra Jr. CEA. Avaliação nutricional de crianças indígenas Pakaanóva (Warí), Rondônia, Brasil. Rev Bras Saude Matern Infant. 2003;3:457-61.

12. Coimbra Jr. CEA, Santos RV. Avaliação do estado nutricional num contexto de mudança sócio-econômica: o grupo indígena Suruí do Estado de Rondônia, Brasil. Cad Saude Publica. $1991 ; 7: 538-62$.

13. Coimbra Jr. CEA, Flowers NM, Salzano FM, Santos RV. The Xavante in transition: health, ecology, and bioanthropology in Central Brazil. Ann Arbor: University of Michigan Press; 2002.

14. Morais MB, Alves GMS, Fagundes-Neto U. Estado nutricional de crianças índias terenas: evolução do peso e estatura e prevalência atual de anemia. J Pediatr (Rio J). 2005;81:383-9.

15. Morais MB, Fagundes-Neto U, Mattos AP, Baruzzi RG. Estado nutricional de crianças índias do Alto Xingu em 1980 e 1992 e evolução pondero-estatural entre o primeiro e o quarto anos de vida. Cad Saude Publica. 2003;19:543-50.

16. Santos RV, Coimbra Jr. CEA. On the (un)natural history of the Tupí-Mondé Indians: bioantropology and change in the Brazilian Amazon. In: Goodman AH, Thomas LL, editors. Building a new biocultural synthesis: political-economic perspectives on human biology. Ann Arbor: University of Michigan Press; 1998. p. 269-94.

17. Coimbra Jr. CEA. Estudos de ecologia humana entre os Suruí do Parque Indígena Aripuanã, Rondônia. Aspectos alimentares. Boletim do Museu Paraense Emílio Goeldi (Série Antropologia). 1985;2:57-87.

18. World Health Organization Expert Committee. Physical status: the use and interpretation of anthropometry. WHO Technical Report Series, 854. Geneva: World Health Organization; 1995.

19. Hamill PV, Drizd TA, Johnson CL, Reed RB, Roche AF, Moore WM. Physical growth: National Center for Health Statistics percentiles. Am J Clin Nutr. 1979;32:607-29.

20. World Health Organization (WHO). Complementary feeding of young children in developing countries: a review of current scientific knowledge. Geneva: World Health Organization; 1998.

21. Orellana JDY. Saúde e nutrição de crianças indígenas Suruí de Rondônia, Amazônia, Brasil [dissertação]. Rio de Janeiro: Escola Nacional de Saúde Pública, Fundação Oswaldo Cruz; 2005.

22. Basta PC. A tuberculose entre o povo indígena Suruí de Rondônia, Amazônia, Brasil [tese]. Rio de Janeiro: Escola Nacional de Saúde Pública, Fundação Oswaldo Cruz; 2005.

23. Escobar AL, Coimbra Jr. CEA, Arias MM, Santos RV. Demografia e saúde reprodutiva dos indígenas Suruí, Rondônia. Cienc Saude Coletiva. 2005;10 Suppl 1:635.

24. Martins SJ, Menezes RC. Evolução do estado nutricional de menores de 5 anos em aldeias indígenas da tribo Parakanã, na Amazônia oriental brasileira (1989-1991). Rev Saude Publica. $1994 ; 28: 1-8$

25. Fagundes $U$, Kopelman B, Oliva CAG, Baruzzi RG, FagundesNeto U. Avaliação do estado nutricional e da composição corporal das crianças índias do Alto Xingu e da etnia Ikpeng. J Pediatr (Rio J). 2004;80:483-9.

26. Palhano-Silva CS, Lourenço AEP, Bastos OMP, Coimbra Jr. CEA, Araújo AJG. Prevalência de parasitoses intestinais na população indígena Suruí, Rondônia, Brasil. Rev Patol Trop. 2005;34 Suppl. CD-ROM.

27. Cardoso AM, Matos IE, Koifman RJ. Prevalência de diabetes mellitus e da síndrome da resistência insulínica nos índios Guarani do Rio de Janeiro. In: Coimbra Jr. CEA, Santos RV, Escobar AL, organizadores. Epidemiologia e saúde dos povos indígenas no Brasil. Rio de Janeiro: Editora Fiocruz; 2003. p. 169-85.

28. Lourenço AEP. Avaliação do estado nutricional em relação a aspectos sócio-econômicos de adultos indígenas Suruí, Rondônia, Brasil [dissertação]. Rio de Janeiro: Escola Nacional de Saúde Pública, Fundação Oswaldo Cruz; 2006.

29. Holmes R. Small is adaptive. Nutritional anthropology of native Amazonians. In: Sponsel LE, editor. Indigenous peoples and the future of Amazonia. Tucson: University of Arizona Press; 1995. p. $121-48$.

Correspondence:

Carlos E. A. Coimbra Jr.

Escola Nacional de Saúde Pública, Fundação Oswaldo Cruz

Rua Leopoldo Bulhões, 1480

CEP 21041-210 - Rio de Janeiro, RJ - Brazil

Tel.: +55 (21) 2598.2683 - Fax: +55 (21) 2598.2610

E-mail: carlos_coimbrajr@gbl.com.br 